Zeszyty Naukowe Szkoły Głównej Gospodarstwa Wiejskiego

Ekonomika i Organizacja Gospodarki Żywnościowej nr 109, 2015: 175-186

Katarzyna Domańska', Tomasz Kijek ${ }^{2}$

Katedra Zarządzania i Marketingu ${ }^{1}$, Katedra Ekonomii i Agrobiznesu ${ }^{2}$

Uniwersytet Przyrodniczy w Lublinie

\title{
Inwestycje w innowacje w przedsiębiorstwach spożywczych zlokalizowanych w województwie lubelskim
}

\section{Wstęp}

Aktualna sytuacja gospodarcza, charakteryzująca się znaczną zmiennością oraz złożonością czynników wpływających na funkcjonowanie przedsiębiorstw sprawia, że kluczowa staje się umiejętność dostosowania się do otoczenia. W związku z tym jednym z najistotniejszych warunków przetrwania i rozwoju przedsiębiorstwa $\mathrm{w}$ gospodarce rynkowej stają się innowacje. Stanowią one odpowiedź podmiotów gospodarczych na zmieniające się, często dynamicznie rosnące, wymagania klientów, a także na działania podejmowane przez konkurentów. W wielu sektorach innowacje wymieniane są wśród kluczowych czynników sukcesu, decydujących o przyszłości organizacji. Zdaniem M.E. Portera [2001, s. 192], przedsiębiorstwo może budować przewagę konkurencyjną przede wszystkim dzięki zdolności do bycia innowacyjnym, ciągłego podnoszenia poziomu innowacyjności i uzyskiwania dzięki temu odpowiedniej efektywności. Znaczenie inwestycji w działalność badawczo-rozwojową dla wyników funkcjonowania organizacji stanowi przedmiot zainteresowania wielu autorów, wśród których można wymienić m.in. E. Mansfielda, Z. Grilichesa, F. Scherera czy M. Rogersa [Hall i in. 2010, s. 1053].

Po raz pierwszy pojęcie innowacji zostało zastosowane przez J. Schumpetera, który wprowadzanie nowych produktów, nowych metod produkcji, znalezienie nowych rynków, zdobycie nowych źródeł surowców oraz wprowadzenie nowej organizacji uznał za przykłady innowacyjnych czynników rozwoju przedsiębiorstwa i wzrostu gospodarki [Schumpeter 1960, s. 104]. Organizacja w wyniku kreowania i wdrażania innowacji może osiagnąć wiele korzyści. Inwestycje pozwalają na poprawę jakości produktu, a tym samym przyczyniają się do podniesienia 
jego wartości z punktu widzenia klienta, co w efekcie wpływa na zwiększanie konkurencyjności podmiotów gospodarczych. Dążenie do osiagnnięcia przewagi konkurencyjnej na rynku jest uznawane za zasadniczy cel wdrażania innowacji w przedsiębiorstwach [Angowski 2013, s. 84]. Ponadto dzięki innowacjom możliwa jest poprawa i unowocześnienie procesów wytwórczych oraz podniesienie produktywności zasobów, wydajności i jakości pracy, co może przełożyć się na obniżenie kosztów produkcji. To z kolei może wpłynąć na zwiększenie ogólnej sprawności i efektywności działania oraz usprawnienie organizacji i metod pracy [Grudzewski i Hejduk 2001, s. 451-452].

Działalność przedsiębiorstwa, polegającą na wprowadzaniu innowacji produktowych, procesowych, rynkowych oraz organizacyjnych [Oslo Manual... 2005, s. 48-52], należy postrzegać w kategorii inwestycji. Szczególnie innowacje produktowe i procesowe wymagają ponoszenia nakładów finansowych na m.in. projektowanie, wykonanie i testowanie wybranych rozwiązań w zakresie nowych lub udoskonalonych materiałów, urządzeń, produktów i procesów, które przyniosą przedsiębiorstwu określone korzyści ekonomiczne w przyszłości. Zgodnie z Międzynarodowymi Standardami Rachunkowości, nakłady na prace rozwojowe, zwiększające zasób wiedzy technologicznej, mogą być kapitalizowane, co pozwala na uwzględnienie ich wpływu na kształtowanie wartości przedsiębiorstwa [Kijek 2012, s. 55].

\section{Czynniki oddziałujące na poziom inwestycji przedsiębiorstw w innowacje}

Zdolność przedsiębiorstwa do prowadzenia i finansowania działań innowacyjnych jest determinowana przez wiele czynników. Na potencjał innowacyjny oddziałują czynniki zlokalizowane zarówno na zewnętrz organizacji, jak i w jej wnętrzu [Włodarczyk i Domańska 2008, s. 165-166]. Ogólnie przyjmuje się, że uwarunkowania ekonomiczne, socjologiczne i psychologiczne decydują o tym, czy przedsiębiorstwo chce wdrażać innowacje, a determinanty o charakterze techniczno-produkcyjnym i organizacyjnym o tym, czy potrafi stworzyć i stosować nowe rozwiązania [Janasz i Kozioł 2007, s. 50].

Na podstawie przeglądu wyników badań z zakresu innowacyjności można wskazać kilka kluczowych czynników decydujących o skali działalności innowacyjnej przedsiębiorstw. Pierwszy z nich to zasięg oddziaływania podmiotu. Przedsiębiorstwa, które prowadzą działalność nie tylko na terenie kraju, ale również poza jego granicami, wykazują większą skłonność do prowadzenia działalności innowacyjnej w porównaniu do podmiotów działających na rynkach regionalnych czy krajowych. Można wskazać kilka prac, które potwierdza- 
ją, że istnieje pozytywny związek między obecnością przedsiębiorstwa na rynkach zagranicznych a poziomem i wzrostem jego wiedzy technologicznej (np. Alvarez i Robertson [2004, s. 79] - badania przeprowadzone wśród podmiotów gospodarczych z Meksyku i Chile; Cassiman i Veugelers [1999, s. 71] - badania belgijskich przedsiębiorstw). Badacze są zgodni co do tego, że większa presja ze strony konkurentów na rynkach międzynarodowych zmusza przedsiębiorstwa do udoskonalania swoich produktów i dostosowania się do nowych warunków rynkowych. Warto również wspomnieć, że Love i Mansury [2009, s. 631-632] sformułowali własną hipotezę uczenia się przez eksport, analizując, czy innowacje napędzają internacjonalizację przedsiębiorstw, czy też umiędzynarodowienie skłania podmioty gospodarcze do podejmowania bardziej innowacyjnych działan.

Jako drugi czynnik przyczyniający się do zwiększenia nakładów na działalność badawczo-rozwojową można wskazać rodzaj wdrażanych innowacji. Jak potwierdzili Parisi i inni [2006, s. 2039], innowacje procesowe są związane z inwestycjami w nowe maszyny i urządzenia będące nośnikami wiedzy uprzedmiotowionej, podczas gdy wydatki na badania i rozwój są bezpośrednio związane $\mathrm{z}$ innowacjami produktowymi.

Wysokość nakładów na działalność badawczo-rozwojową jest także uzależniona od źródła ich finansowania. Nakłady te są wyższe w przypadku przedsiębiorstw finansujących innowacje ze środków własnych (w porównaniu do podmiotów korzystających ze środków obcych). Brown i inni [2009, s. 168], którzy uważają, że większość finansowania dla przedsiębiorstw zaawansowanych technologii pochodzi ze źródeł wewnętrznych, jako pierwsi podkreślili znaczenie finansowania działalności badawczo-rozwojowej w przemyśle high-tech ze środków publicznych. Wyniki ich badań wskazują, że podmioty z sektora high-tech finansują działalność innowacyjną głównie z przepływów środków pieniężnych, ze względu na wysokie koszty oraz trudności związane z uzyskaniem finansowania zewnętrznego.

Nie bez znaczenia dla poziomu nakładów na innowacje pozostaje również wielkość przedsiębiorstwa. Podmioty średnie i duże przeznaczają wyższe nakłady na kreowanie i wdrażanie innowacji niż przedsiębiorstwa małe ze względu na większe możliwości w zakresie ich finansowania zarówno kapitałem własnym, jak i obcym. Duże podmioty mogą wykorzystywać efekt skali w działalności innowacyjnej oraz szybciej osiagać korzyści z innowacji w porównaniu do małych przedsiębiorstw. Co więcej, są one w stanie sfinansować działalność innowacyjną ze środków własnych [Cohen 2010, s. 132-140]. Metaanaliza badań empirycznych dotyczących działalności innowacyjnej w przemyśle przeprowadzona przez Becheikh'a i innych [2006, s. 651-652] wykazała, że wielkość przedsiębiorstwa odgrywa istotną rolę w aktywności innowacyjnej przedsiębiorstw. 
Kolejnym czynnikiem wpływającym na wysokość inwestycji w innowacje jest zakres współpracy przedsiębiorstwa z innymi podmiotami. Podejmowanie działań kooperacyjnych prowadzi do optymalizacji (redukcji) nakładów na innowacje, gdyż rozkładają się one na wszystkie współpracujące ze sobą podmioty. Z kolei kooperacja w zakresie działalności innowacyjnej z innymi przedsiębiorstwami pozwala wyraźnie ograniczyć ryzyko dla współpracujących stron i przyczynia się do poprawy ich pozycji na rynku [Baumol 1992, s. 134]. Ponadto współpraca prowadzi do zmniejszenia nakładów na badania i rozwój, a tym samym redukuje intensywność nakładów na innowacje.

Ostatnim z czynników, który może przyczyniać się do wzrostu inwestycji w innowacje, jest zakres szkoleń dla pracowników. Wzrost nakładów na szkolenia pracowników prowadzi do wzrostu nakładów na działalność badawczo-rozwojową ze względu na zwiększenie świadomości pracowników w zakresie znaczenia, możliwości i korzyści związanych z wprowadzaniem innowacji. Wśród korzyści z pozyskiwania wiedzy zewnętrznej należy wymienić możliwość zatrudniania pracowników o wysokim poziomie wykształcenia i doświadczenia, wnoszących do przedsiębiorstwa określone kompetencje w zakresie innowacji. Wśród nielicznych badań empirycznych dotyczących tej problematyki Ballot $\mathrm{i}$ inni [2001, s. 455] udowadniają, że szkolenia w miejscu pracy mają pozytywny wpływ na produktywność działalności badawczo-rozwojowej. Kapitał ludzki jest czynnikiem, który decyduje o zdolności do absorpcji przejawiającej się w umiejętności pozyskania, przyswojenia i wykorzystania nowej wiedzy, w tym wiedzy technologicznej [Cohen i Levinthal 1990, s. 128].

\section{Cel i metodyka badań}

Celem niniejszego opracowania była identyfikacja skali oraz charakteru inwestycji w innowacje podejmowanych przez przedsiębiorstwa z branży spożywczej zlokalizowane w województwie lubelskim. W opracowaniu podjęto również próbę określenia czynników kształtujących nakłady na innowacje w badanych podmiotach oraz ustalenie kierunku ich wpływu. W pracy zostały sformułowane następujące pytania badawcze:

1. Jakiego rodzaju innowacje dominują w przedsiębiorstwach?

2. Jakie są motywy wdrażania innowacji przez przedsiębiorstwa?

3. Czy i ewentualnie z kim współpracują przedsiębiorstwa przy kreowaniu innowacji?

4. Jakie są główne źródła finansowania działalności innowacyjnej przez przedsiębiorstwa? 
5. Jakie czynniki determinują wzrost nakładów na działalność innowacyjną przedsiębiorstw?

Próbę badawczą stanowiło 40 przedsiębiorstw z branży spożywczej prowadzących działalność gospodarczą na terenie województwa lubelskiego. Dane pochodzą z badań ankietowych przeprowadzonych w 2012 roku przez Urząd Statystyczny w Lublinie w ramach projektu Kapitał intelektualny Lubelszczyzny 2010-1013. Badania dotyczyły wybranych aspektów funkcjonowania przedsiębiorstw w 2011 roku kluczowych z punktu widzenia rozwoju województwa lubelskiego.

Wszystkie badane przedsiębiorstwa stanowiły prywatną własność krajowa, a jedynie jedno z nich zadeklarowało udział kapitału zagranicznego. Siedzibę podmiotów w większości przypadków stanowiło małe miasto lub wieś - po 37,5\%, a pozostała 1/4 przedsiębiorstw była zlokalizowana w dużych miastach. Średni okres działalności badanych podmiotów wynosił 29 lat, w tym przedsiębiorstwa funkcjonujące na rynku do 10 lat stanowiły $5,0 \%$, od 11 do 20 lat $-32,5 \%$, od 21 do 30 lat $-45,0 \%$, od 31 do 50 lat $-5,0 \%$, powyżej 50 lat $-12,5 \%$.

Biorąc pod uwagę kryterium wielkości zatrudnienia, w próbie badawczej znalazło się 12,5\% mikroprzedsiębiorstw (do 9 zatrudnionych), 42,5\% przedsiębiorstw małych (zatrudniających od 10 do 49 osób), 32,5\% średnich (od 50 do 249 pracowników) oraz 12,5\% dużych (zatrudniających przynajmniej 250 osób). Średnie zatrudnienie kształtowało się na poziomie 118 pracowników. Średnie roczne obroty wynosiły w 2011 roku 36534 tys. zł, przy czym przychody nieprzekraczające 1000 tys. zł osiagało $27,5 \%$, od 1001 do 10000 tys. zł $-35,0 \%$, od 10001 do 50000 tys. zł - 22,5\%, a powyżej 50000 tys. zł - 15,0\%.

W celu określenia czynników oddziałujących na poziom nakładów na działalność innowacyjną zastosowano model regresji liniowej, gdzie za zmienną zależną przyjęto wysokość nakładów na badania i rozwój w 2011 roku - Y, zaś do zmiennych objaśniających zaliczono: $X_{1}$ - udział eksportu w produkcji sprzedanej; $X_{2}$-udoskonalenie, modernizacja dotychczasowych produktów; $X_{3}-$ wprowadzenie nowych produktów; $X_{4}$ - wdrożenie nowych procesów; $X_{5}$ - udoskonalenie/modernizacja dotychczasowych procesów; $X_{6}$ - zakres współpracy z innymi przedsiębiorstwami; $X_{7}-$ wielkość zatrudnienia; $X_{8}$-stopień finansowania majątku kapitałem własnym; $X_{9}$ - wysokość nakładów na szkolenia w zakresie działalności innowacyjnej. Zgodnie z podejściem strukturalnym, dobór zmiennych objaśniających został dokonany na podstawie przesłanek teoretycznych przedstawionych w poprzednim punkcie opracowania.

Do estymacji parametrów modelu regresji liniowej zastosowano klasyczną metodę najmniejszych kwadratów. W celu wyboru optymalnego zbioru zmiennych objaśniających zastosowano procedurę regresji krokowej wstecznej. 


\section{Wyniki badań}

Spośród badanych przedsiębiorstw spożywczych 18 podmiotów $(45,0 \%)$ zadeklarowało $\mathrm{w} 2011$ roku prowadzenie działan projektowych i przygotowawczych czy też opracowywanie nowych procedur mających na celu wdrożenie nowych produktów, procesów lub rozwiązań organizacyjnych. Średnia kwota przeznaczona na ten cel kształtowała się na poziomie $116154 \mathrm{zl}$, przy czym nakłady na działalność innowacyjną wahały się od 1000 do 300000 zł. Z kolei w 15 badanych przedsiębiorstwach $(37,5 \%)$ w 2011 roku zostały wdrożone innowacje. Ze względu na fakt, iż liczba podmiotów, które podjęły działania przygotowawcze do wprowadzania innowacji, przewyższa liczbę przedsiębiorstw, które innowacje już wdrożyły, można spodziewać się w przyszłości zwiększenia aktywności innowacyjnej.

Forma wdrożonych innowacji w badanych przedsiębiorstwach była bardzo zróżnicowana (rys. 1). Wśród nich dominowały innowacje produktowe - wdrożenie nowych produktów zadeklarowało $73,3 \%$ badanych podmiotów, a udoskonalenie lub modernizację posiadanych w strukturze asortymentowej produk-

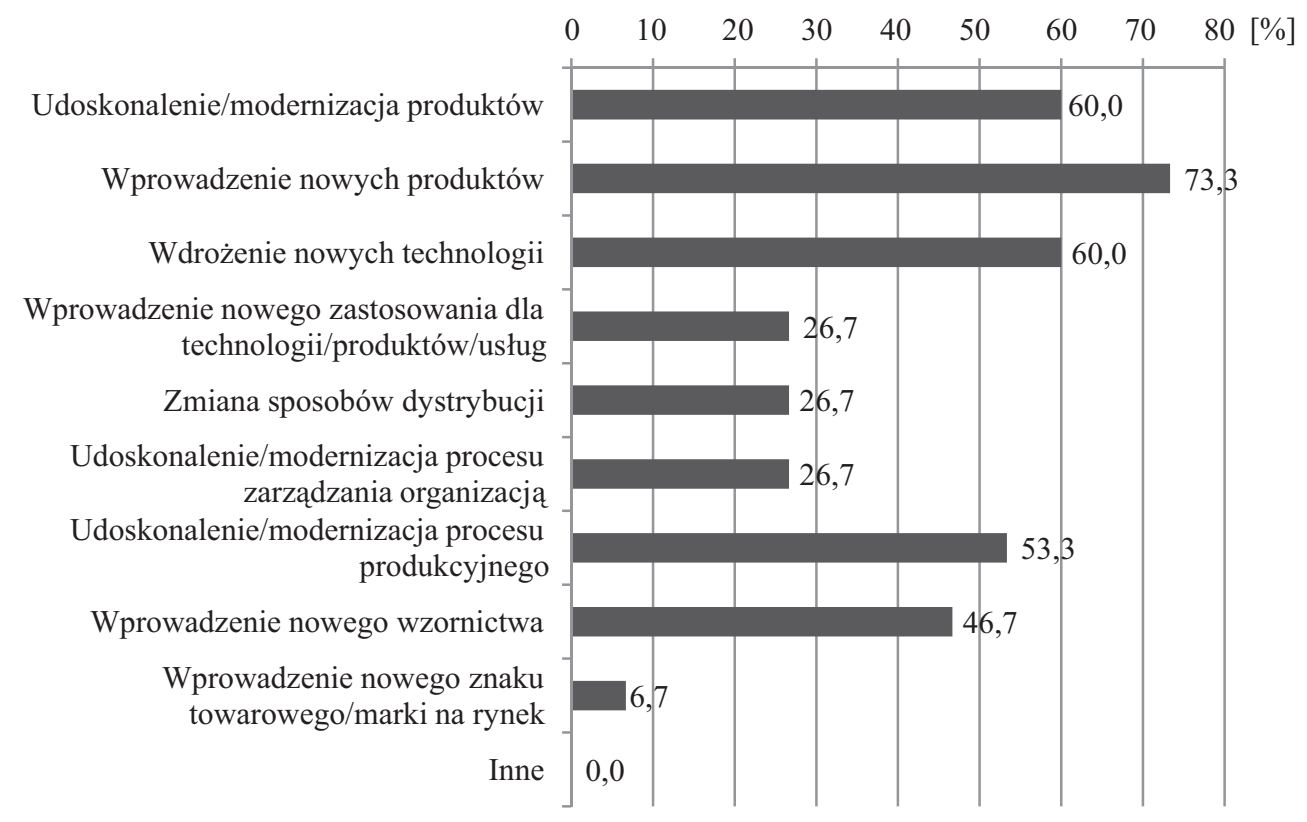

\section{Rysunek 1}

Forma wdrożonych innowacji w przedsiębiorstwach przemysłu spożywczego w województwie lubelskim w 2011 roku

Źródło: Opracowanie własne. 
tów $-60,0 \%$. Poza tym $46,7 \%$ analizowanych podmiotów wprowadziło zmiany w zakresie wzornictwa wytwarzanych wyrobów.

Znaczącą rolę miały również innowacje o charakterze procesowym. Ponad połowa ankietowanych przedsiębiorstw dokonała wdrożenia nowych technologii $(60,0 \%) \mathrm{i} / \mathrm{lub}$ zmian w procesie produkcyjnym $(53,3 \%)$. Najmniejsza grupa podmiotów zdecydowała się w 2011 roku na nowe rozwiązania w zakresie działalności marketingowej - tylko $6,7 \%$ przedsiębiorstw wprowadziło na rynek nowy znak towarowy lub nową markę.

Podjęcie działań innowacyjnych przez podmioty gospodarcze funkcjonujące w branży spożywczej w województwie lubelskim było spowodowane w dużej mierze przez dążenie do zwiększenia konkurencyjności (rys. 2).

Aż 80,0\% przedsiębiorstw dzięki wdrożonym innowacjom chciała poprawić jakość swoich produktów lub usług, aby ich oferta rynkowa była konkurencyjna w odniesieniu do ofert rywali rynkowych. Bardzo istotnym motywem wprowadzania zmian okazały się również działania mające na celu zwiększenie udziału w rynku $(73,3 \%)$, utrzymanie pozycji na rynku $(66,7 \%)$ oraz zdobycie nowych rynków zbytu $(53,3 \%)$. Należy podkreślić, że tylko $1 / 3$ badanych podmiotów wprowadzała innowacje, aby zmniejszyć koszty działalności.

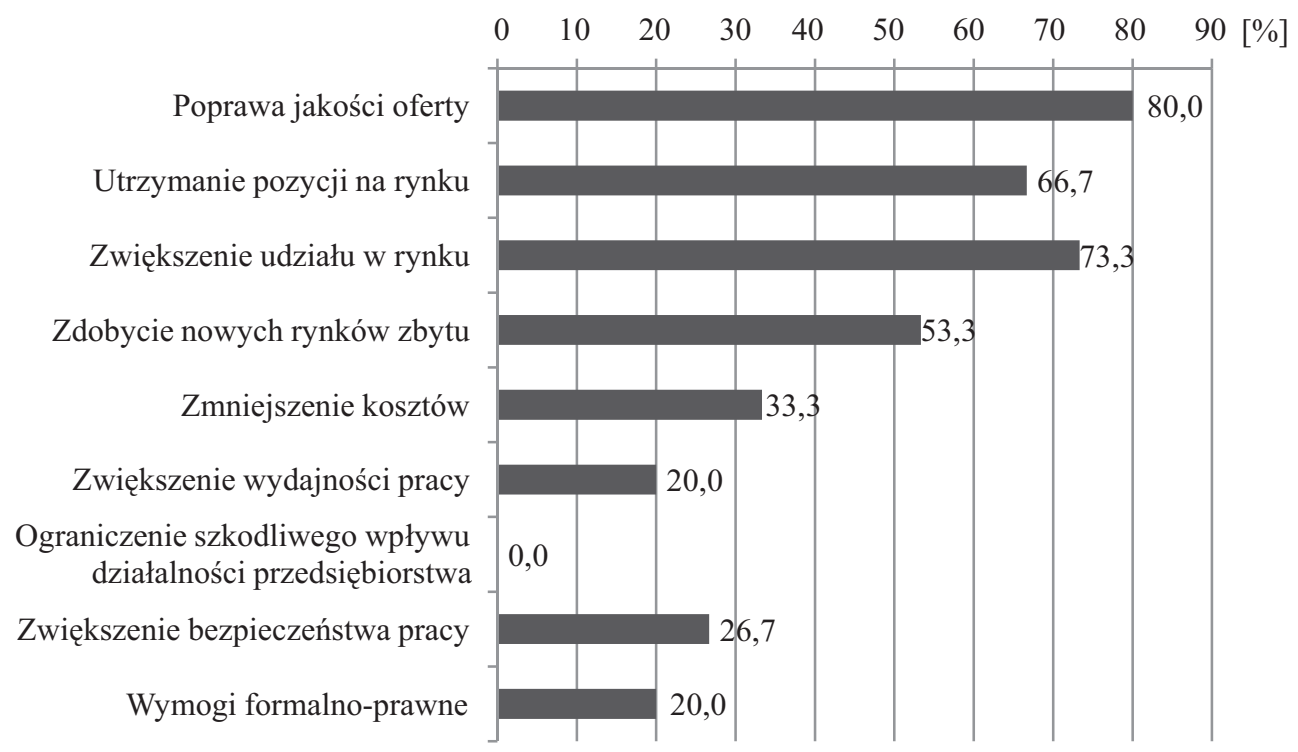

\section{Rysunek 2}

Motywy wprowadzania innowacji w przedsiębiorstwach przemysłu spożywczego w województwie lubelskim w 2011 roku

Źródło: Opracowanie własne. 
Wprowadzane innowacje były przede wszystkim generowane przez przedsiębiorstwa je wdrażające bądź też podmioty z nimi powiązane (73,3\%; rys. 3).

Około 1/5 ankietowanych podmiotów zadeklarowała współpracę z innymi przedsiębiorstwami przy tworzeniu nowych rozwiązań. Tylko 13,3\% tworzyło innowacje we współpracy z jednostkami badawczo-rozwojowymi, przy czym żadne z przedsiębiorstw nie wdrożyło innowacji opracowanych samodzielnie przez jednostki tego typu. Należy zwrócić uwagę na fakt, iż dla niecałych 7\% spośród analizowanych podmiotów źródło innowacji stanowiły inne przedsiębiorstwa.

Zdecydowana większość badanych podmiotów finansowała działalność innowacyjną z kapitału własnego (93,3\%; rys. 4).

Stosunkowo często wykorzystywanymi źródłami finansowania były także kredyty bankowe oraz programy współfinansowane ze środków Unii Europejskiej - po 40,0\% ankietowanych zadeklarowało korzystanie z tego typu finansowania innowacji. Tylko $6,7 \%$ przedsiębiorstw skorzystało ze środków pochodzących z programów w całości finansowanych ze środków krajowych, natomiast 1/5 podmiotów zdecydowała się na wykorzystanie leasingu w celu wdrożenia innowacji. Należy podkreślić, że ani jedno $\mathrm{z}$ ankietowanych przedsiębiorstw nie skorzystało z takich źródeł, jak: kredyt bankowy uzyskany dzięki funduszowi poręczeniowemu, fundusz pożyczkowy oraz emisja akcji lub obligacji.

W tabeli 1 zamieszczono wyniki estymacji parametrów modelu regresji liniowej przedstawiającego relacje między aktywnością innowacyjną przedsiębiorstw, aproksymowaną przez wydatki na działalność badawczo-rozwojowa, a czynnikami ją determinującymi. Na podstawie zastosowanych miar stopnia dopasowania modelu do danych empirycznych można stwierdzić, że zbudowany model pozwala wyjaśnić około $66 \%$ zmienności modelowanej zmiennej zależ-

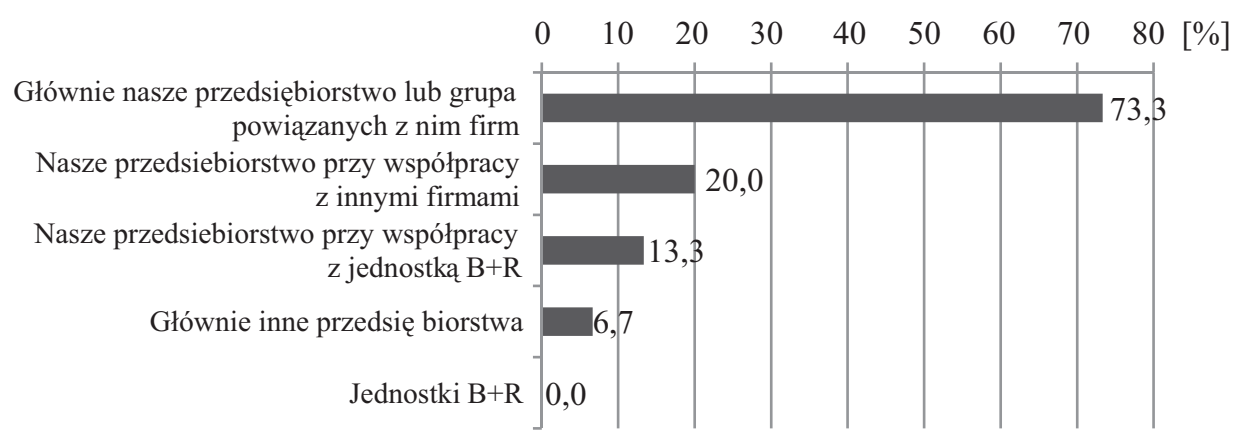

\section{Rysunek 3}

Źródła pochodzenia innowacji w przedsiębiorstwach przemysłu spożywczego w województwie lubelskim w 2011 roku

Źródło: Opracowanie własne. 


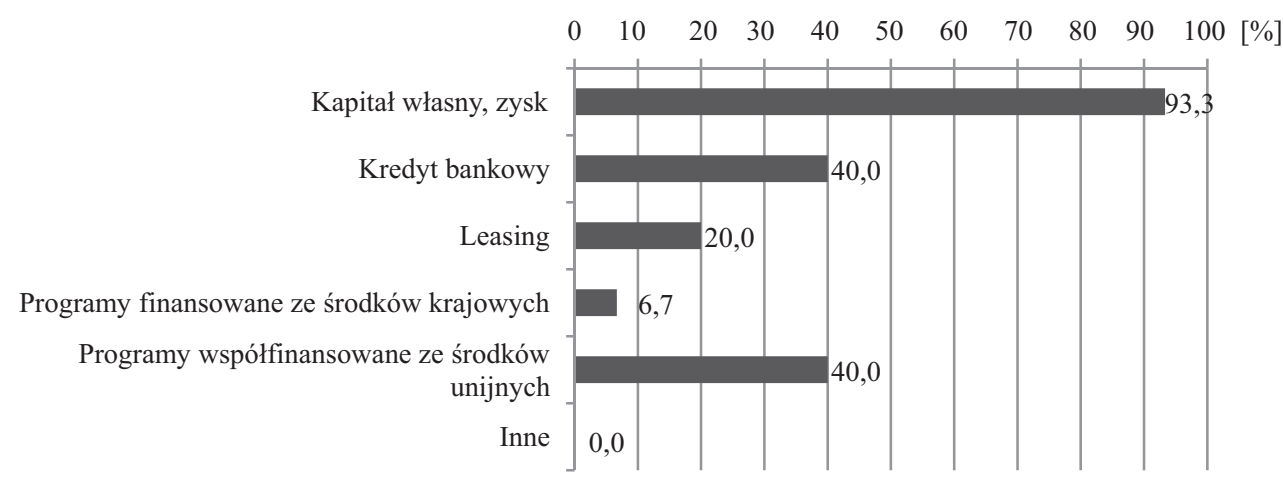

\section{Rysunek 4}

Żródła nakładów na innowacje w przedsiębiorstwach przemysłu spożywczego w województwie lubelskim w 2011 roku

Źródło: Opracowanie własne.

\section{Tabela 1}

Wyniki estymacji i weryfikacji parametrów modelu regresji liniowej

\begin{tabular}{|c|c|c|c|c|}
\hline Zmienne & Współczynnik & Błąd standardowy & t-Studenta & Wartość $p$ \\
\hline Constans & 46715,80 & 36096,80 & 1,29 & 0,02 \\
\hline$X_{1}$ & 1793,12 & 590,73 & 3,03 & 0,01 \\
\hline$X_{2}$ & -194606 & 54954 & $-3,54$ & 0,01 \\
\hline$X_{3}$ & 226387 & 38271,30 & 5,91 & 0,00 \\
\hline$X_{4}$ & $\times$ & - & - & - \\
\hline$X_{5}$ & $\times$ & - & - & - \\
\hline$X_{6}$ & $-59606,60$ & 32537,20 & $-1,72$ & 0,10 \\
\hline$X_{7}$ & $\times$ & - & - & - \\
\hline$X_{8}$ & $\times$ & - & - & - \\
\hline$X_{9}$ & $\times$ & - & - & - \\
\hline
\end{tabular}

$X$ - zmienna (nieistotna) wyeliminowana z modelu; $\mathrm{R}^{2}=0,66, \mathrm{~F}=32,49, \mathrm{p}=0,00$

Źródło: Opracowanie własne.

nej. Wartość statystyki F i odpowiadający jej poziom prawdopodobieństwa testowego $p$ potwierdzają istotny statystycznie związek liniowy.

Przeprowadzone badania wskazują, że dodatnio na wzrost nakładów na działalność innowacyjną w badanych przedsiębiorstwach przemysłu spożywczego w województwie lubelskim oddziaływały dwa czynniki: zakres działalności podmiotu poza granicami kraju (mierzony udziałem eksportu w przychodach) 
oraz skłonność do wprowadzania nowych produktów. Należy zaznaczyć, iż to drugi z wymienionych czynników najbardziej wpływał na zwiększenie nakładów na badania i rozwój.

Z kolei takie czynniki jak wprowadzenie modyfikacji produktu oraz współpraca $\mathrm{z}$ innymi podmiotami $\mathrm{w}$ zakresie kreowania $\mathrm{i} / \mathrm{lub}$ wdrażania innowacji wpływały na obniżenie nakładów związanych z działalnością innowacyjną w ankietowanych przedsiębiorstwach. Pierwsza zależność możne wynikać z faktu, iż modyfikacja lub udoskonalenie produktu często nie wymagają prowadzenia prac badawczo-rozwojowych, gdyż bazują na dostępnej wiedzy technicznej. Z kolei kooperacja w zakresie działalności innowacyjnej pozwala na zmniejszenie nakładów na badania i rozwój.

Na podstawie przeprowadzonej analizy takich czynników, jak: wprowadzanie innowacji procesowych, stopień finansowania innowacji kapitałem własnym, wielkość przedsiębiorstwa mierzona wielkością zatrudnienia oraz wysokość nakładów na szkolenia pracowników dotyczące problematyki innowacji, zostały uznane za nieistotne z punktu widzenia wysokości ponoszonych przez badane przedsiębiorstwa nakładów na działalność innowacyjną.

\section{Wnioski}

Badania dotyczące działalności innowacyjnej przedsiębiorstw spożywczych prowadzących działalność gospodarczą w województwie lubelskim pozwoliły na sformułowanie następujących wniosków:

1. Wśród wdrażanych innowacji $\mathrm{w}$ ankietowanych przedsiębiorstwach dominowały innowacje produktowe oraz procesowe. Najmniej liczna grupa zdecydowała się w 2011 roku na nowe rozwiązania w zakresie działalności marketingowej. Koncentracja przedsiębiorstw na innowacjach produktowych i procesowych z jednej strony może świadczyć o znacznym potencjale technologicznym organizacji, z drugiej strony może wskazywać na ograniczone zdolności/kompetencje marketingowe.

2. Głównym motywem wdrażania innowacji było dążenie do zwiększenia konkurencyjności. Bardzo istotnym motywem wprowadzania zmian okazały się również działania mające na celu zwiększenie udziału w rynku, utrzymanie pozycji na rynku oraz zdobycie nowych rynków zbytu. Wymienione motywy sugerują, iż pomimo niedoceniania wagi innowacji w sferze marketingu, przedsiębiorstwa mają świadomość, że ich sukces zależy przede wszystkim od uwarunkowań rynkowych, a prowadzona przez nich działalność innowacyjna stanowi odpowiedź na zmieniające się potrzeby nabywców.

3. Wprowadzane innowacje były przede wszystkim generowane przez przedsiębiorstwa je wdrażające bądź też podmioty z nimi powiązane. Należy 
podkreślić, iż niewiele przedsiębiorstw tworzyło innowacje we współpracy $\mathrm{z}$ jednostkami badawczo-rozwojowymi, przy czym żaden $\mathrm{z}$ badanych podmiotów nie wdrożył innowacji opracowanych samodzielnie przez jednostki tego typu. Pomimo uruchomienia w ostatnich latach wielu działań mających na celu poprawę współpracy między nauką a praktyką, nie udało się jednak osiagnąć zadowalających efektów w tym zakresie. Taka sytuacja może wynikać z niedopasowanej do oczekiwań rynkowych podaży technologii ze strony jednostek badawczo-rozwojowych, z innej strony może to być wynik braku wiedzy na temat przedsiębiorców innowacyjnych rozwiązań.

4. Zdecydowana większość badanych przedsiębiorstw finansowała działalność innowacyjną z kapitału własnego. Stosunkowo często wykorzystywanymi źródłami finansowania były także kredyty bankowe oraz programy współfinansowane ze środków Unii Europejskiej. Potwierdza to słuszność koncepcji wsparcia innowacyjności z unijnego budżetu, a zatem za zasadne należy uznać kontynuowanie takiej polityki w nowej perspektywie finansowej.

5. Dodatnio na wzrost nakładów na działalność innowacyjną w badanych przedsiębiorstwach przemysłu spożywczego w województwie lubelskim oddziaływały dwa czynniki: zakres działalności podmiotu poza granicami kraju oraz wprowadzanie nowych produktów. Z kolei takie czynniki jak wprowadzenie modyfikacji produktu oraz współpraca z innymi podmiotami w zakresie kreowania i/lub wdrażania innowacji wpływały na obniżenie nakładów związanych z działalnością innowacyjną.

\section{Literatura}

ALVAREZ R., ROBERTSON R., 2004: Exposure to foreign markets and plant-level innovation: evidence from Chile and Mexico, Journal of International Trade \& Economic Development, Taylor and Francis Journals, 13(1).

ANGOWSKI M., 2013: Innovation as part of a strategy of maximizing the competitive position of small and medium-sized enterprises in rural areas, Współczesne Zarządzanie $12(2)$.

BALLOT G., FAKHFAKH F., TAYMAZ E., 2001: Firms' human capital, R\&D and performance: a study on French and Swedish firms. Labour Economics 8.

BAUMOL W.J., 1992: Horizontal collusion and innovation. Economic Journal 102(410).

BECHEIKH N., LANDRY R., AMARA N., 2006: Lessons from innovation empirical studies in the manufacturing sector: A systematic review of the literature from 1993-2003. Technovation. May/Jun2006, Vol. 26, Issue 5/6.

BROWN J.R., FAZZARI S.M., PETERSEN B.C., 2009: Financing innovation and growth: Cash flow, external equity, and the 1990s R\&D boom, Journal of Finance, 64(1).

CASSIMAN B., VEUGELERS, R., 1999: Make and Buy in Innovation Strategies: Evidence from Belgian Manufacturing Firms, Research Policy 28. 
COHEN W.M., 2010: Fifty years of empirical studies of innovative activity and performance, B. Hall, N. Rosenberg (red.), Handbook of the economics of innovation, Elsevier, Amsterdam.

COHEN W.M., LEVINTHAL D.A., 1990: ABSORPTIVE CAPACITY: A NEW PERSPECTIVE ON LEARNING AND INNOVATION, Administrative Science Quarterly 35(1).

GRUDZEWSKI W., HEJDUK I., 2001: Projektowanie systemów zarzqdzania, Difin, Warszawa.

HALL B., MAIRESSE J., MOHNEN P., 2010: MEASURING THE RETURNS TO R\&D, [w:] B. Hall, N. Rosenberg (red.), Handbook of the economics of innovation, tom 2, Elsevier, New York.

JANASZ W., KOZIOŁ K., 2007: Determinanty działalności innowacyjnej przedsiębiorstw, PWE, Warszawa.

KIJEK T., 2012: Innovation capital and its measurement, Journal of Entrepreneurship, Management and Innovation (JEMI) 8(4).

LOVE J.H., MANSURY M.A., 2009: Exporting and productivity in business services: Evidence from the United States, International Business Review, 18.

Oslo manual. Guidelines for collecting and interpreting innovation data, OECD Publishing, $3^{\text {rd }}$ Edition, 2005.

PARISI M.L., SCHIANTARELLI F., SEMBENELLI A., 2006: Productivity, innovation and $R \& D$ : Micro evidence for Italy, European Economic Review 50(8).

PORTER M.E., 2001: PORTER O KONKURENCYJNOŚCI, PWE, Warszawa.

SCHUMPETER J., 1960: Teoria rozwoju gospodarczego, Wydawnictwo Naukowe PWN, Warszawa.

WŁODARCZYK A., DOMAŃSKA K., 2008: Innowacje $w$ działalności MSP agrobiznesu, [w:] M. Adamowicz (red.). Innowacje i innowacyjność w sektorze agrobiznesu, Rolnictwo, przemyst spożywczy, konsumenci, Prace Naukowe SGGW tom I, 45, Katedra Polityki Agrarnej i Marketingu.

\section{Investments in innovations: the case of food producers from the Lubelskie region}

\section{Abstract}

Nowadays, innovations are the key driver of a firm's development and sustainability. This paper identifies and examines the scale and type of investments in innovations in the sample of food producers from Lubelskie region. Moreover, the paper tries both to identify the drivers of the level of expenditures on innovations and to discover the direction of impact. According to the research results, $45.0 \%$ of the surveyed enterprises were engaged in innovation activities, while $37.5 \%$ of surveyed enterprises introduced innovations in the year 2011. The results of the study reveal that the propensity to introduce new products and operating outside the country stimulate the firms to invest in innovations. 